\title{
Impact of Organizational Culture on Human Resource Practices: A Study of Selected Nigerian Private Universities
}

\section{Osibanjo Omotayo Adewale, Adeniji Adenike Anthonia}

\begin{abstract}
This paper shows results of the impact of organizational culture on human resource practices in some selected Nigerian private universities. The statistical analysis was based on two hundred and thirty-seven respondents in the selected studied private universities showing that a close relationship exists between organizational culture and recruitment process, training programmes, job performance management, performance of employees, pay structure, and compensation administration. The paper suggested that given the organizational context of the study, each of the variables will be appreciated more by the individuals in values, beliefs, and practices of the organization. It is therefore suggested that prospective employees or job seekers should endeavor to familiarize themselves with the organizational culture before accepting job offers.
\end{abstract}

Keywords: Organizational Culture, Private Universities, Nigeria, Human Resource Practices JEL Classification: $M 12$

\section{INTRODUCTION}

Today's organization is predominantly dynamic as it poses large opportunities and challenges to the corporate practitioners and policy makers. Understanding such dynamism is very crucial to pursue the organizational strategic objectives.

There have been researches in literature to explore the effect of organizational culture on various human resource development programmes of an organization. For example, scholars including Hofstede, 1980; Ouchi, 1981; Hofstede and Bond, 1988, Kotter and Heskett, 1992; Magee, 2002, claim that organizational culture help to provide opportunity and broad structure for the development of human resources' technical and behavioural skills in an organization. This makes sense because good behavior is driven by ethical values. An organization can guide the conduct of its employees by embedding ethical values in its culture. However, organizational excellences could be varied since cultural traits could be source of competitive advantage through casual ambiguity, (Barney, 1991; and Peters and Waterman, 1982). The world is changing rapidly and the level of organizations is also changing due to technological advancements which have affected their human resource developments programmes. Moreover, organizations differ in their cultural content in terms of the relative ordering of beliefs, values and assumptions.

Organizational culture adapts overtime to cope with the dynamic changes and meet the varying demands of the organization in its quest for gaining competitive advantage in all its activities. Therefore, a supportive culture as noted by Ritchie, (2000) is considered as a motivational instrument which promotes the organization to perform smoothly and ensure success in all its 
endeavours. Thus, the aim of this paper is to examine the impact of organizational culture on the human resource development programmes of organizations using selected Nigerian Private Universities as our study case. The choice of Nigerian private universities was based on the fact that these universities were birthed from different perspectives, some are privately owned by Christians and Islamic missionaries, which is evident in the differences that exist amongst them and exhibited in their value, belief, and practices. However, universities owned by the government (State or Federal) are not captured in this survey.

However, the paper seeks to answer the following research questions:

- Does organizational culture has any significance influence on the recruitment and selection activity of an organization?

- Do training and development programmes of an organization affected by the organizational culture?

- Is there any significant relationship between the culture of an organization and the compensation administration?

- Are performance management functions of an organization directly related to the organizational culture?

\section{LITERATURE REVIEW}

\subsection{Contents of Organizational Culture}

Organizational culture is conceptualized as shared beliefs and values within the organization that helps to shape the behavior patterns of employees (Kotter and Heskett, 1992). Gordon and Cummins (1989) define organization culture as the drive that recognizes the efforts and contributions of the organizational members and provides holistic understanding of what and how to be achieved, how goals are interrelated, and how each employee could attain goals. Hofstede (1990) summarizes organization culture as collective process of the mind that differentiates the members of one group from the other one. Thus, we can deduce from above definitions that organizational culture could be the means of keeping employees in line and acclimatizing them towards organizational objectives. Deal and Kennedy, (1982) recognizes the link between culture and organizational excellent performances via its human resource development programmes. These cultural values and human resource development programmes are consistent with organizational chosen strategies that led to successful organizations. The organizational culture is outlined in Schein (1990) as overall phenomenon of the organization such as natural settings, the rite and rituals, climate, values and programmes of the company e.g. performance management, training and development, recruitment and selection, etc. According to Martins and Terblanche (2003), culture is deeply associated with values and beliefs shared by personnel in an organization. Organizational culture relates the employees to Organization's values, norms, stories, beliefs and principles and incorporates these assumptions into them as activity and behavioural set of standards. Klein, (1996) positioned organizational culture as the core of organization's activities which has aggregate impact on its overall effectiveness and the quality of its product and services. Schein (2004) defined organizational culture as a dynamic force within 
the organization which is revolving, engaging and interactive and it is shaped up by the employees and management gestures, behaviours and attitudes.

Organizational culture is the basic pattern of shared assumptions, values and beliefs considered to be the correct way of thinking about and acting on problems and opportunities facing the organization. It is what is important and unimportant in the organization. It is often thought of as organization' DNA- i.e. invisible to the naked eye, yet a powerful template that shapes what happens in the workplace. Hence why Schneider and Smith (2004) argues that culture begins with leadership and passed on to the organizational members; it is seen as a set of forces that shape and determine human behavior.

The culture of an organization is brought about as a result of different factors some of which include the influences of national culture, previous events in the organization, the different personalities and the socialization individual members experienced as a result of past educational and work settings (Mahler, 1997). It includes the assumptions, values and beliefs of organization. Assumptions are the shared mental models, the broad worldviews or theories in use that people rely on to guide their perceptions and behaviours, for example, employees assume that the company's integrity to employees/staff compensation administration is one of the keys to the company's survival and success. Organization's beliefs represent the individual's perceptions of reality.

Organizations differ in their cultural content in terms of the relative ordering of beliefs, values and assumptions. For instance, some organization practices place a premium on their recruitment and selection, training and development programmes, compensation administration and even, performance management. Also, some place a premium on career development, goal setting and pay-for-performance, all with the intent of maximizing employee performance and customer service. This will help to create a culture of high performance across the organization.

Some organizations support employee wellbeing with free medical care, personal trainers, inexpensive cafeteria, unlimited sick days, heavily subsidized day care, etc.

Organizational culture affects corporate performance. Corporate culture is a deeply embedded form of social control that influences employee decisions and behavior.

Culture is pervasive and operates unconsciously. It is an automatic pilot directing employees in ways that are consistent with organizational expectations.

Organizational culture is the social glue that bonds people together and makes them feel part of the organizational experience. Employees are motivated to internalize the organization's dominant culture because it fulfils their needs for social identity. This social glue serves as a way to attract new staff and retain top performers.

Again, corporate culture assists the sense-making process. It helps employees understand organizational events. They can get on with the task at hand rather than spend time trying to figure out what is expected of them. Employees can also communicate more efficiently and reach higher levels of cooperation with each other because they share common mental models of reality.

An organizational culture can also influence the recruitment and selection activities of an organization. This makes sense because good behavior is driven by ethical values. An organization can guide the conduct of its employees by embedding ethical values in its culture. 


\subsection{Organizational Culture and Recruitment cum Selection.}

Accurate employee selection decisions have never been more important to organizational success. Organizations need quality staff that can operate in an environment of increasing complexity and change. Also, in a business environment where intellectual capital increasingly represents an organization's currency of trade, it is people that create and sustain an organization's competitive advantage.

Hiring the wrong person for the job can be costly. The time and expenses associated with advertising, agency fees, interviewing candidates and the negative long term financial and non-financial implications of hiring the wrong person make finding and hiring the right person critical. Traditionally, organizations have focused on identifying and selecting people based on their skills and experience. It makes sense if one can find person who has the right set of skills and has done a similar job. There is a good chance that they will be able to perform effectively in a new role. Though skills and experience continue to be important, practice however pointed to motivational fit as a key differentiator in the selection process. Chartman, (2001) defines motivational fit in two distinct ways, i.e. job fit motivation and organization fit motivation.

Job fit motivation is the degree to which the activities and responsibilities of a particular job are consistent with the activities and responsibilities that an individual finds personally satisfying while organization fit motivation is the individual's compatibility with an organization's values and mode of operation. Organizational fit covers a range of organizational attributes which is the most common and frequently cited element that centers on the congruence between individual and organizational values. It is also called 'culture fit'. While these two constructs play important roles in making effective hiring decisions, Cable and Judge, (1996) believe organizational fit increasingly represents the key. Most times, organizations fail to consider motivational fit and in particular organizational fit. However, as a result of increasing complexity, change and employee demands, information about organizational fit can help organizations make better hiring decisions. Numerous research results illustrate the importance of the congruence between the values of the individual and the values and culture of the organization. The importance of recruiting for culture fit cannot be overemphasized because of its impact on making good recruitment decisions is supported by the impact of poor culture fit decisions. It helps to reduce absenteeism and turnover. Also, assessing for fit helps the organizations increase employee satisfaction and morale, which leads to better performance and productivity. Motivated employees are more likely to take charge of their own performance, seek ways to improve processes, products and services and contribute positively to their organization's bottom line success. Because job dissatisfaction is the leading cause of voluntary turnover and is directly linked to lower productivity and morale, it makes sense to consider and assess for fit during the recruitment process. Thus, the importance of values and values integration throughout the recruitment process is imminent.

Moreover, the following recommendations for integrating culture fit were summarized from literature, these include;

a) Ensure that every managers and individuals in the organization are adequately trained in recruitment practices including behavioural interviewing, motivational fit concepts and interpretation of recruitment data. 
b) Describe values in behavioural terms and use behavioural based questions to assess suitability. It also includes identifying competencies that align with the core values and ensure that the interview questions are constructed to address these.

c) Use tools like Realistic Job Previews or Day in the Life profiles to help applicants selfscreen. These ensures applicants better understand the dynamics of a particular job and organization and make decisions early enough about suitability for the position and many applicants may self-screen themselves out of the recruitment process.

d) Utilize motivational fit tool. These involve three steps. (i) Analyze the job and organizational characteristics that are present or absent in the role and the organization to determine a job and organization profile. (ii) Ask prospective employees to complete a motivational questionnaire to provide information about characteristics they will find appealing or disappealing in an ideal organization and job. (iii) Compare the organization and individual profiles to determine suitability and fit.

However, in order to meet the organizational objectives and achieve competitive advantages, all organizations are thriving to recruit highly performing individuals. On the other hand, individuals need supportive organizational culture to help them reach individual objectives. Thus, an organization is a consciously coordinated system where characteristics of individuals, groups and organization interact with each other and effective interaction among them highly depends on organizational culture that shapes the individual performance, (Kozlowski and Klein, 2000). Carr, Schmidt, Ford, and DeShon, (2003) submitted that the culture of an organization has direct relationship with the performance appraisal system, compensation, employee motivation, training and development, flexible time system, organizational structure, employee satisfaction, etc. Going by the aforementioned, we propose the following hypothesis;

Hypothesis 1: Organizational culture has no significance influence on the recruitment and selection activity of an organization.

Furthermore, recruitment process in most of the Nigerian private universities is usually structured to accommodate their newly graduated students, who begin as graduate assistants; and at this level work experience is not a requirement for employment.

\subsection{Organizational culture and Training cum Development}

Training is the planned efforts by an organization to facilitate employee's learning of job-related competencies. These competencies include knowledge, skills or behaviours that are critical for successful job performance. Training and development help in optimizing the utilization of human resource that further helps the employee to achieve the organizational goals as well as their individual goals (Adeniji, Osibanjo, and Abiodun, 2013). It also helps to develop and improve the organizational culture within the organization through building the positive perception and feelings about the organization.

However, training and development helps in creating a better corporate image, thus aid in organizational development, i.e. organization gets more effective in decision making and problem solving which helps in understanding and carrying out organizational policies. Training and development demonstrates a commitment to keeping employees on the cutting edge of knowledge and practice. 
Creativity and innovation also trigger the performance of employees and facilitated by organizational culture which training and development programmes provide. Tushman and O'Reilly (2002) stated that organizational culture lies at the heart of organizational norms that reflects the influence of organizational culture on creativity and innovation. It also play an important role in creating such an environment that enables learning and innovative response to challenges, competitive threats or new opportunities. Thus, creating and influencing an adaptive culture is one of a manager's most important jobs and which training and development programmes avail the opportunities (Daft, 2010).

Precise information and applicable knowledge usually made available via training and development always assist performance, whereas erroneous information and irrational knowledge are likely to do the opposite, (Feldman and March, 1991; Daft and Weick, 1994). Not only that, cultures provide cognitive frameworks through which people interpret what they observe and experience and provide language and referents to use in communicating with others, (Wilkins and Ouchi, 2003). Culture through the different training and development activities contribute schemas and scripts that can affect performance by providing preexisting ways of understanding what is occurring, how to evaluate it and what sequences of actions are appropriate to the situation (Lord and Foti, 1996).

However, Siegal and Sussman (2003), asserted gaining competitive advantage which surrounds knowledge adoption and helps to integrate the organizational culture and social presence can actually explain information sharing process which comes via training and development programmes. Thus, we come up with the proposition;

Hypothesis 2: Training and development programmes of an organization are directly affected by the organizational culture.

\subsection{Organizational Culture and Performance Management}

Organizational development has certain factors that improve sustainability on the basis of effectiveness. The improvements in productivity lead to employee commitment as norms, values and objectives help in improving culture of an organization. The system of organization was based upon effective establishment of culture that keep learning environment strong. The performance of employees improves by establishment of strong culture of an organization. The employee performance is considered to be the backbone of the organization as it leads to the growth and development of organization. Thus, the loyalty of employee relies upon knowledge and awareness of culture that improves behavior of organization, (Brooks, 2006). The awareness of quality helps in improving organizational and employee development. The degree of an achievement to which an employee fulfils the organizational mission at workplace is what is referred to as performance, (Cascio, 2006). The assignment of an employee is build up by degree of achievement of a particular target or mission that defines boundaries of performance, though the capability of an organization to establish a perfect relationship with resources presents effective and efficient management of resources, (Cascio, 2006, Daft, 2000; and Stannack, 2006). However, in order to achieve goals and objectives of organization, strategies have to be designed based upon organizational performance. The performance measurement system helps in improving organization association to achieve goals and objectives at an effective manner (Richardo, 2006). The 
strategic planning based upon development of goals and objectives help organization to focus non-financial otherwise known as intangible assets, while quality, performance and services linked with customers have financial nature, (Kaplan and Norton, 2011). The measurement of performance based upon financial and non-financial performance leads to competitiveness, (Chenhall, 2005).

The strategies based upon well designed human resource development policies and programmes help in making culture more effective. Kaplan and Norton (2011) defined four casual relationships between performance management and culture as the learning growth, customers, internal business process (from efficient and effective human resource development activities), and financial reward management systems, all of which help in improving and presenting casual relationship. The culture and performance have been interrelated to each other based upon perfect association between business processes, (Reichers and Schneider, 1999).

Several researches had been carried out to evaluate performance of organizations based upon efforts as culture had been given significant association. The four contributions on culture defined include; power distance, individualism, uncertainty avoidance and masculinity.

Power distance is the degree of employee and management behavior that have been based upon perfect relationship between formal and informal set of planning action and individualism is the dimension of difference between organization interest and self-interest. The uncertainty ambiguity based upon tolerance helps in mitigating willingness of people, while masculinity comes in avoidance of caring and promotion than level of success based upon challenges and ambition.

Culture and performance were considered interrelated to each other by nature and scope of culture. The competitive advantage of an organization is attained through strong association and establishment of culture. The organization culture helps in measuring limitation to overcome performance measurement, (Rousseau, 2000).

According to Brooks (2006), the job performance of organization has a strong impact of strong organization culture which leads to enhance productivity, and that the productivity and culture of organization helps in improving performance. It is in the line of this idea that the norms and values of organization based upon different cultures influence on workforce management which enables effective and efficient management of workforce that we propose the following hypothesis;

Hypothesis 3: Performance management function of an organization is directly related to the organizational culture.

\subsection{Organizational Culture and Compensation Administration}

Compensation administration is a segment of management or human resource management that focuses on planning, organizing and controlling the direct and indirect payments employees receive for the work they perform. Compensation comprises of direct forms such as base merit and incentive pay; also indirect forms such as vacation pay, deferred payment, etc.

It is often said that a general model of compensation administration focus on the culture of the organization and encompasses the creation and management of a pay system based on four basic interrelated policy decisions including internal consistency (i.e. the organizational culture), 
external competitiveness, employee contributions and administration of the compensation programmes. Compensation professionals work with these policy decisions according to the organizational culture and individual corporations' needs keeping in mind the ultimate objectives of compensation administration- efficiency, equity and compliance. Companies develop their individual compensation strategies by placing varying degrees of emphasis on the four policy decision mentioned above including the culture of the organization.

Compensation administrators always seek to achieve internal equity and consistency, i.e. rationalizing pay within a single organization through the analysis, description, evaluation, organizational culture and structure of jobs (Adeniji and Osibanjo, 2012). This requires the compensation administrator to compare job titles, skill levels together with the culture of work and remuneration to determine the contributions employees with different jobs and titles make towards accomplishing company objectives. Thus, compensation administrators should consider internal consistency when determining pay rates for employees who do the same work and employees who do different works in accordance with the culture on ground in the organization. The different values organizations have for employees with different jobs and skill levels reflect the culture of the organization. The internal consistency depends on how a company is structured which reflect the structure and culture of the organization. The pay structure of an organization is its range of pay rates for different jobs and skill levels within the organization. In other words, that pay structures reflect corporate culture.

Moreover, the following are the primary but interrelated factors that can shape a company's pay culture;

1. Social customs; economic forces alone do not determine wages but the current notion of a federally mandated minimum wage which evolve from the employee demanding a just wage which always go with the remuneration culture of the organization on ground. Thus, this suggests that the organizational culture has a positive relationship with the compensation administration.

2. Job requirements; some jobs may require greater skills, knowledge or experience than others, hence attract a higher pay rate.

3. Employee Acceptance; employees expect fair pay rates and compare their wages with their co-workers and supervisor's rate of pay. If they consider their par rates as unfair, they may file a law suit, reduce their output or seek employment elsewhere.

4. Employee Knowledge and Skills: employees bring different levels of skills and knowledge to organizations, hence they can work at different levels of a company hierarchy and receive different rates of pay as a result.

5. Company Factors; pay structures depend on the kind of technology an organization adopts and whether an organization uses pay as an incentive to motivate employees to improve job performance and to accept more responsibilities.

Not only that, achieving external competitiveness in the area of compensation means balancing the need to keep operating costs low with the need to attract and retain quality workers which is in line with the corporate culture of cost minimization. It is how an organization's rate of pay 
compares to those of its competitors. Compensation administrators achieve external competitiveness by comparing wage levels within their industry, examining their company's resources and goals, corporate culture and establishing their own pay levels accordingly. Companies can set their pay levels to lead, match or follow competitor's pay practices which are part of a company's culture. An Organization's culture of compensation administration involves the weight an organization chose to place on employee performance in determining a compensation programmes. Some organizations may choose to pay all employees the same wage while others may decide to reward employee for seniority or productivity.

This approach enables companies to give their employees a measure of control over their compensation and thereby influence their performance. This is a corporate culture that employees are importantly motivated by pay. Several objective methods of compensation for performance have become popular overtime among which include; profit sharing incentive schemes, employee stock option, the bonus scheme, gain sharing scheme and the 13th month pay. These methods of compensation programmes encourage employees to be more cost and efficiency conscious and to be forthcoming in suggestions that can further improve operations. They tie incentives to increased productivity, quality improvements, time savings and cost savings. These programmes are geared towards making each employee's vested interest in the company clearer and more immediate through their pay check. This is a corporate culture that helps control labour costs because employees do not receive the rewards unless the company performs well.

Going by the aforementioned, compensation administration involves determining whether the pay programmes will attract and retain needed employees successfully, whether employees consider the pay programmes as fair, how competitors pay their employees and how compensation administration help control labour costs which are consistent with the corporate culture. Hence, we come up with the research hypothesis;

Hypothesis 4: Organizational culture has no significance relationship with compensation administration of an organization.

\section{RESEARCH MODEL AND HYPOTHESES}

This study will focus on the effects of Human Resource Development activities such as recruitment and selection, training and development, performance management and compensation administration on Organizational Culture. Based on the literature presented above, the following research model is proposed in fig. 1. 


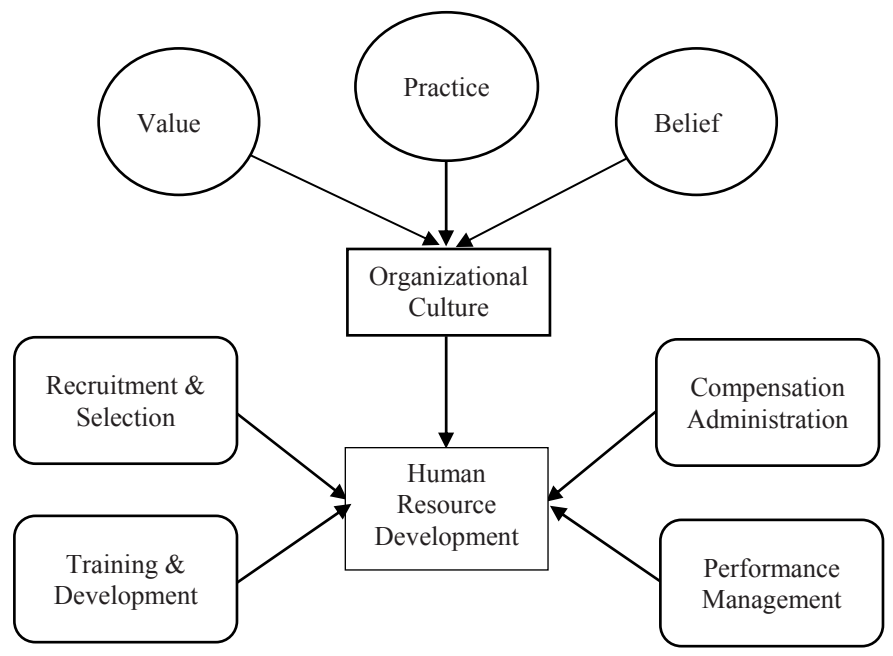

Fig. 1: The Proposed Research Model. Source: Survey, 2012

\subsection{Research Methodology}

\section{Sampling and Data Collection}

Private Universities in Nigeria is experiencing rapid growth in the recent times and these institutions are owned by religious groups (Christians; Moslems; and individuals). Therefore the population consists of:

(i) Covenant University, Ota, Ogun State (Christians)

(ii) Crescent University, Abeokuta, Ogun State (Moslems); and

(iii) The Bells Technology, Ota, Ogun State (Individual)

The target population of this study consists of academic from the list above.

Cluster and stratified random sampling approaches were adopted for this study because of the nature and behavioural pattern of the profession in the Nigerian private universities; and the survey was limited to Ogun State, Southwest Nigeria. The study instrument was administered to the respondents through a personal contact and appropriate guidelines were provided to respondents in answering the questions. The real time required filling the questionnaire is about five minutes. The Statistical Package for Social Science (SPSS) version 16 was used to analyze and test the hypotheses, in order to determine the relative association between the studied variables. The valid sample completed by academics from the studied universities were 237.

The choice of Private universities for the study rest on the fact that these institutions were birthed by individual or religious groups. Therefore, they tend to differ in their views, belief, value, and practices upon which these universities were built. These universities cannot be compared with the Federal and State Universities that were built and govern by government constitution and policies. 


\subsection{Research Instrument}

Structured questionnaire was used in collecting primary data for the study, which was divided into two sections. The first part requires respondent demography such as gender, age, marital status and work experience. While the second part contains sixteen (16) items structured around the hypothesised statements that were based on five-point Likert scale ( 5 = Strongly Agree; 4 = Agree; $3=$ Undecided; $2=$ Disagree; and $1=$ Strongly Disagree $)$ in which respondents were expected to either agree or disagree. The sixteen items consist of statements measuring organizational culture and recruitment and selection; degree to which organizational value and belief affect training and development; impact of practices, value, and belief on performance management; and also the effect of organizational practices and belief on compensation administration. Furthermore, these items were compiled by the researchers based on literature reviewed. The reliability test was conducted using Cronbach's alpha in order to determine the internal consistency of the instrument adopted and the coefficient value was .859, which is greater than .7 (acceptable value). Therefore, the scale used for this survey can then be considered reliable.

\section{DATA ANALYSIS}

\subsection{Respondents Characteristics}

As indicated in Tab 1, the sample size comprises of $57.8 \%$ males and $42.2 \%$ females, which is evident that the representation of the male is higher than the female counterpart. Generally, the greater percentage of the respondents fall within the age bracket of $26-35$ years of age $(51.0 \%)$, followed by 18 - 25years of age with $30.0 \%$; and the least in the age category is respondents within the age bracket of 46 years and above. It is therefore evident that the respondents could be considered as appropriate because the majority fall within the age bracket that are agile and active and drives economy of any nation. In similar direction, $44.7 \%$ of the participants were married; which is evident that they have been able to remain in their marriages despite all odds and challenges. However, about $37.6 \%$ were single, while $12.7 \%$ were divorced.

The respondents could be classified as relatively experienced because $46.8 \%$ have worked between 6 - 10 years; while $17.7 \%$ have worked for eleven years and above. This could be as a result of the age of the institutions, which falls between $5-10$ years, it could also be attributed to the high rate of turnover which is one of the characteristics of private sector of any economy.

Further, the $30 \%$ representing the age category (18 - 25years) of the respondents could be as a result of the employment policy that exists among these private universities, which allows reabsorbtion of their graduates as faculty members at early stage and groom them to maturity. However, it is important to note that majority of the undergraduates were admitted between the age 16 and 18, and complete their 4-year study within the age bracket of $20-22$. These new faculty members often refer to as "Graduate Assistants" begin their academic career early, and it is a common practice among private universities in Nigeria. 
Tab. 1 - Respondents Characteristics. Source: Survey, 2012

\begin{tabular}{|c|c|c|}
\hline & Frequency & Percentage \\
\hline \multicolumn{3}{|l|}{ Gender } \\
\hline Male & 137 & $57.8 \%$ \\
\hline Female & 100 & $42.2 \%$ \\
\hline Total: & 237 & $100.0 \%$ \\
\hline \multicolumn{3}{|l|}{ Age } \\
\hline $18-25$ years & 71 & $30.0 \%$ \\
\hline $26-35$ years & 121 & $51.0 \%$ \\
\hline $36-45$ years & 28 & $11.8 \%$ \\
\hline Above 46 years & 17 & $7.2 \%$ \\
\hline Total: & 237 & $100.0 \%$ \\
\hline \multicolumn{3}{|l|}{ Marital Status } \\
\hline Single & 89 & $37.6 \%$ \\
\hline Married & 106 & $44.7 \%$ \\
\hline Divorced & 30 & $12.7 \%$ \\
\hline Others & 12 & $5.0 \%$ \\
\hline Total: & 237 & $100.0 \%$ \\
\hline \multicolumn{3}{|l|}{ Work Experience } \\
\hline $0-5$ years & 81 & $34.2 \%$ \\
\hline $6-10$ years & 111 & $46.8 \%$ \\
\hline 11 years \& above & 42 & $17.7 \%$ \\
\hline Missing System & 3 & $1.3 \%$ \\
\hline Total: & 237 & $100.0 \%$ \\
\hline
\end{tabular}

\subsection{Relationship between Variables analyzed}

As obtained in Tab. 2, it is observed that medium association exists amongst the studied variables. Recruitment process show positive relationship with organization culture (value, belief and practice) where $r=.201$. Recruitment process is positively related to individual objective ( $\mathrm{r}$ $=.406$ ), this relationship could be attributed to the prior knowledge of the employees regarding the institution' values, belief, and practice. In other words, prospective job seekers tend to seek information about the institutions regarding their culture. Similarly, high association exists between individual value and individual objective $(\mathrm{r}=.540)$, an explanation to this is that individual value tends to reflect in individual objective. In other words, individual objective is expected to be in line with his value. Significant relationship between training and development and individual objective $(\mathrm{r}=.383)$ has some explanation in development of employees in organizations, whereby individual objectives are expected to align with the organizational goal; in similar direction, the significant relationship that exist between training and development and recruitment process $(r=.387)$ is an indication that training and development is a follow-up of the recruitment process which must be closely aligned. Organizational development and infor- 
mation sharing was found to be positively related $(\mathrm{r}=.462)$, which is an indication that organization tends to develop when workers are timely and adequately informed. Generally, the variables of the study are positively related; an explanation for this could be associated with the fact that employment seekers tend to search jobs where they can achieve their career goals; therefore efforts are being made to ensure that organizational culture does tally or align with their individual belief, value and practice. However, it is essential to note that some job seekers only search for jobs that can pay their bills not minding their individual belief, value, or practice.

Tab. 2 - Correlation Matrix of Variables. Source: Survey, 2012

\begin{tabular}{|l|c|c|c|c|c|c|c|}
\hline & 1 & 2 & 3 & 4 & 5 & 6 & 7 \\
\hline Organizational Culture & 1 & & & & & & \\
\hline Individual Objective & $.193^{* *}$ & 1 & & & & & \\
\hline Recruitment Process & $.201^{* *}$ & $.406^{* *}$ & 1 & & & & \\
\hline Individual value & $.176^{* *}$ & $.540^{* *}$ & $.394^{* *}$ & 1 & & & \\
\hline Information Share & $.141^{*}$ & $.244^{* *}$ & $.165^{*}$ & $.337^{* *}$ & 1 & & \\
\hline Training \& Development & $.149^{*}$ & $.383^{* *}$ & $.387^{* *}$ & $.276^{* *}$ & $.160^{*}$ & 1 & \\
\hline $\begin{array}{l}\text { Organizational Develop- } \\
\text { ment }\end{array}$ & -.052 & $.258^{* *}$ & .124 & $.269^{* *}$ & $.462^{* *}$ & $.201^{* *}$ & 1 \\
\hline
\end{tabular}

*Correlation is significant at the 0.05 level (2-tailed), ** correlation is significant at the 0.01 level (2-tailed)

The results regression analysis conducted to test the research model between human resource development and organizational culture is as shown in Tab. 3. The model explains the association between organizational culture (value, belief, and practice) and human resource development (recruitment and selection; training and development; compensation; and performance appraisal). In comparing the contribution of each independent variable, as observed in Tab. 3, under Beta column, recruitment process makes the strongest unique contribution to explaining the dependent construct (organizational culture - value, belief, and practice), which is represented with .284 beta coefficient. Followed by training programmes with .200 beta coefficient, which could be interpreted as training programmes making $20.0 \%$ contribution to the dependent construct. Looking at the column marked Sig., it is evident that recruitment process variable $($ sig. $=.000)$; and training programmes (sig. $=001)$ are making significant unique contribution to the prediction of the study dependent construct. However, a close analysis of model parameters indicated that two of the variables have close association with the organizational culture (belief, value, and practice). It is however probable that given the organizational context of the study, recruitment process, training and development, compensation management and performance appraisal may have organizational culture (belief, value and practice) undertone, which may be more appreciated by individuals who might have some similarities with the values, belief, and practice of the organization. Further, the institutions studied must have made their recruitment process and training and development aligned with the organizational culture. In addition, employment seekers are fully aware of their expectations right from the recruitment and selection process, thereby have the right to accept or decline employment offer. 
Tab. 3 - Coefficientsa Source: Survey, 2012

\begin{tabular}{|c|c|c|c|c|c|c|}
\hline & \multirow[t]{2}{*}{ Model } & \multicolumn{2}{|c|}{$\begin{array}{c}\text { Unstandardized } \\
\text { Coefficients }\end{array}$} & \multirow{2}{*}{$\begin{array}{c}\begin{array}{c}\text { Standardized } \\
\text { Coefficients. }\end{array} \\
\text { Beta }\end{array}$} & \multirow[t]{2}{*}{$\mathrm{T}$} & \multirow[t]{2}{*}{ Sig } \\
\hline & & B & Std. Error & & & \\
\hline \multirow[t]{8}{*}{1} & (Constant) & 1.244 & .405 & & 3.074 & .002 \\
\hline & Recruitment Process & .231 & .057 & .284 & 4.034 & .000 \\
\hline & Training programmes & .200 & .060 & .200 & 3.353 & .001 \\
\hline & Job performance mgt & .065 & .059 & .070 & 1.104 & .271 \\
\hline & Performance of employees & .042 & .074 & .046 & .564 & .573 \\
\hline & Pay structure & -.068 & .051 & -.085 & -1.318 & .189 \\
\hline & Compensation admin. & -.052 & .050 & -.070 & -1.043 & .298 \\
\hline & External competitiveness & .130 & .050 & .179 & 2.610 & .010 \\
\hline
\end{tabular}

a. Dependent Variable: Organizational culture; $\mathrm{R} 2=.304 ; \mathrm{R}=.551 ; \mathrm{F}=10.701 ; \mathrm{Sig}=.000$

\section{MANAGERIAL IMPLICATIONS AND CONCLUSIONS}

The results of this study suggest that there is close relationship between recruitment process and organizational culture (belief, value, and practice). The implication of this for managers or recruiters agency is that recruitment process being the first point of interaction between the organization and the prospective employees, could serve as the right avenue to disseminate vital information about the organization to the job seekers. Further, this will enhance the alignment of intending employees with the organizational belief, value, and practices, which attempt to ensure a proper match. Thereby accelerating human capital development within the organization, which tends to reduce labour turnover. In the same vein, the association that exists between training programmes and organizational value, belief, and practice implies that management or decision makers in institutions should endeavor to incorporate their belief, value and practices in the training and development programme designed for the employees. This will further sustain organizational culture and help employees (new or old) adapt to organization's culture. Further, among the three-stage process in which employees pass through within organization; it is essential noting that the most critical period for employees is at the initial entry point, the stage at which employees who fail to learn are labelled "nonconformists" and this may lead to termination. Thus, being familiar with the organizational culture (values, beliefs, and practices) will help employees understand organizational events, thereby helping them to get along with the task at hand rather than wasting time trying to figure out what is expected of them.

\subsection{Limitation of the Study}

The study was based solely on the effect of Human Resource Development (HRD), which comprises of recruitment and selection; training and development; compensation administration; and performance management on Organizational Culture (value, belief, and practice) in the Nigeria Educational Industry, using private institutions as case study. However, the study can also be done on the other criteria that may have either direct or indirect impact on the performance of organization. Further, for better results, we suggest comparison of previous research with the 
current study, which tends to provide a wide view regarding the studied variables. We used cross sectional method in this research which means that research will conduct once a time. But we can also use Longitudinal Method for better results by making comparison of previous research with the current research. It will be more helpful for the researcher and the organizations to take better decisions for achievements of the strategic goals.

\section{References}

1. Adeniji, A. A., \& Osibanjo, A. O. (2012). Human Resource Management: Theory \& Practice. Lagos, Nigeria: Pumark Nigeria Limited.

2. Adeniji, A. A., Osibanjo, A. O., \& Abiodun, A. J. (2013). Organizational Change and Human Resource Management Interventions: An Investigation of the Nigerian Banking Industry. Serbian Journal of Management, 8(2), 139-154. http://dx.doi.org/10.5937/sjm8-3712

3. Barney, J. B. (1986). Organizational Culture: Can it be a Source of Sustained Competitive Advantage? Academy of Management Review, 11(3), 656-665. http://dx.doi.org/10.2307/258317

4. Brooks, I. (2006). Organizational Behaviour: Individuals, Groups and Organization. Essex: Pearson Education Limited.

5. Cable, D. M., \& Judge, T. A. (1996). Person-Organization Fit, Job Choice Decision and Organization Entry. Organizational Behaviour and Human Decision Process, 67(3), 294-311. http://dx.doi.org/10.1006/obhd.1996.0081

6. Carr, M. J., Schmidt, W. T., Ford, A. M., \& DeShon, D.J (2003). Job Satisfaction: A MetaAnalysis of Stabilities. Journal of Organisational Behaviour, 22(3), 483-504.

7. Cascio, W. F. (2006). Managing Human Resources: Productivity, Quality of Life, Profits. New York: McGraw-Hill/Irwin.

8. Chartman, J. A. (1989). Improving Interactional Organizational Research: A Model of Person Organization Fit. Academy of Management Review, 14(3), 333-349.

9. Chenhall, R. H. (2005). Integrative Strategic Performance System, Strategic Alignment of Manufacturing, Learning and Strategic Outcomes: An Exploratory Study. Accounting, Organizations and Society, 30(5), 394-420.

10. Daft, R. L., \& Weick, K. E. (1994). Toward a Model of Organizations as Interpretation Systems. Academy of Management Review, 9(2), 284-297.

11. Daft, R. L. (2000). Organization Theory and Design. USA: South-Western College Publishing, Thompson Learning.

12. Deal, T. E., \& Kennedy, A. A. (1982). Corporate Cultures: The Rites and Rituals of Corporate Life. Harmondsworth: Penguin Books.

13. Feldman, M., \& March, J. (1981). Information as Signal and Symbol. Administrative Science Quarterly, 26(2), 171-186. http://dx.doi.org/10.2307/2392467

14. Gordon, G., \& Cummins, W. (1979). Managing Management Climate. Toronto, Canada: Lexington Books. 
15. Gordon, G., \& DiTomaso, N. (1992). Predicting Corporate Performance from Organizational Culture. Journal of Management Studies, 29(6), 783-798. http://dx.doi. org/10.1111/j.1467-6486.1992.tb00689.x

16. Guest, D. E. (2001). Human Resource Management: When Research Confronts Theory. International Journal of Human Resource Management, 12(7), 1092-1106. http://dx.doi.org/10.108 0/09585190110067837

17. Hofstede, G. (1980). Culture's Consequences: International Differences in Work Related Issues. Beverly Hills, CA: Sage.

18. Hofstede, G. (1980). Motivation, Leadership and Organization: Do American Theories Apply Abroad? Organizational Dynamics, 9(1), 42-63. http://dx.doi.org/10.1016/00902616(80)90013-3

19. Hofstede, G., Neuijen, B., Ohayv, D. D., \& Sanders, G. (1990). Measuring Organizational Cultures: A. Qualitative and Quantitative Study Across Twenty Cases. Administrative Science Quarterly, 35(2), 286-316. http://dx.doi.org/10.2307/2393392

20. Kaplan, R. S., \& Norton, D. P. (2011). The Strategy-focused Organization: How Balanced Scorecard Companies Thrive in the New Business Environment. Boston, MA: Harvard Business School Press.

21. Khanna, T., \& Palepi, G. (2004). The Evolution of Concentrated Ownership in India. Broad Patterns and a History of the India Software Industry. Working paper No. 10613. National Bureau of Economic Research, Cambridge.

22. Khatri, N. (2000). Managing Human Resource for Competitive Advantage. A Study of Companies in Singapore. International Journal of Human Resource Management, 11(2), 336-365. http://dx.doi.org/10.1080/095851900339909

23. Klein, A. (1996). Validity and Reliability for Competency-Based Systems: Reducing Litigation Risks. Compensation and Benefits Review, 28(4), 31-47. http://dx.doi.org/10.1177/088 636879602800405

24. Kotter, E. H., \& Heskett, O. K. (1992). Culture: The Missing Concept in Organizational Studies. Administrative Science Quarterly, 4(2), 229-240.

25. Kozlowski, S. W., \& Klein, K. J. (2000). A Multilevel Approach to Theory and Research in Organizations: Contextual, Temporal and Emergent Processes. In K. J. Klein \& S. W. Kozlowski (Eds.). A Multilevel Theory, Research and Methods in Organizations (pp. 7-93). San Francisco: Kossey-Bass.

26. Lord, R. G., Foti, R. J., \& DeVader, C. I. (1984). A Test of Leadership Categorization Theory: Internal structure, information processing, and leadership perceptions. Organizational Behaviour and Human Performance, 34(3), 8343-376. http://dx.doi. org/10.1016/0030-5073(84)90043-6

27. Magee, K. C. (2002). The Impact of Organizational Culture on the Implementation of Performance Management. Doctoral Dissertation.

28. Mahler, J. (1997). Influences of Organizational Culture on Learning in Public Agencies. Journal of Public Administration, Research and Theory, 7(4), 519-540. 
29. Martins, E. C., \& Terblanche, F. (2003). Building Organizational Culture that Stimulates Creativity and Innovation. European Journal of Innovation Management, 6(1), 64-74. http:// dx.doi.org/10.1108/14601060310456337

30. Martin, J., Frost, P., \& O’Neill, O. (2006). Organizational culture: Beyond struggles for intellectual dominance. In S. Clegg, C. Hardy, T. Lawrence, \& W. Nord (Eds.), The SAGE handbook of organization studies. (pp. 725-754). London: SAGE Publications Ltd. http://dx.doi. org/10.4135/9781848608030.n26

31. Martins, E. C. (2000). The Influence or Organizational Culture on Creativity and Innovation in a University Library. MInf Dissertation, University of South Africa, Pretoria.

32. Mathew, J. (2007). The Relationship of Organizational Culture with Productivity and Quality: A Study of India Software Organizations. Employee Relations, 29(6), 677-697.

33. Mirander, S. M., \& Saunders, C. S. (2003). The Social Construction of Perspective on Information Sharing, Information Systems. An Alternative Motivation and Development. San Francisco: JosseyBass.

34. Ouchi, W. G. (1981). Theory Z: How American Business can meet the Japanese Challenge. Business Horizons, 24(6), 82-83. http://dx.doi.org/10.1016/0007-6813(81)90031-8

35. Parker, M. (2000). Organizational Culture and identity. London: Sage.

36. Patterson, M., Warr, P., \& West, M. (2004). Organizational Climate and Company Productivity: The Role of Employee Affect and Employee Level. Journal of Occupational and Organizational Psychology, 77(2), 193-216. http://dx.doi.org/10.1348/096317904774202144

37. Peters, T. J., \& Waterman, R. H. (1984). In search of Excellence. New York, NY: Harper \& Row.

38. Ravasi, D., \& Schultz, M. (2006). Responding to Original Identity Threats: Exploring the Role of Organizational Culture. Academy of Management Journal, 49(3), 433-458. http://dx.doi. org/10.5465/AMJ.2006.21794663

39. Riechers, A \& Schneider, B. (1999). Climate and Culture: An Evolution of Constructs. In Schneider, B. (Ed.), Organizational Climate and Culture (pp. 5-40). San Francisco, CA.: Jossey-Bass.

40. Richardo, R. (2006). Corporate Culture Revolution: The Management Development Imperative. Journal of Managerial Psychology, 11(2), 3-11.

41. Ritchie, M. (2000). Organizational Culture: An Examination of its Effect on the Initialization Process and Member Performance. Southern Business Review, 25, 1-16.

42. Rousseau, D. (2000). Quantitative Assessment of Organizational Culture. Group and Organizations Studies, 15(4), 448-460.

43. Schein, E. H. (1990). Organizational Culture. American Psychologist. 45(2), 109-119. http:// dx.doi.org/10.1037//0003-066X.45.2.109

44. Schein, E. M. (2003). Organizational Culture and Leadership. San Fransisco, CA:Jossey-Bass.

45. Schneider, B., \& Smith, D. B. (2004). Personality and Organizational Culture. In B.

Scheneider \& D. B. Smith (Eds.), Personality and Organization (pp. 347-369). Mahwah, New Jersey: Lawrence Erlbaum Associates. 
46. Siegal, U., \& Sussman, S. W. (2003). Informational Influence in Organization: An Integrated Approach to Knowledge Adoption. Information Systems Research, 14(1), 47-65.

47. Stannack, P. (1996). Perspectives on Employees Performance. Management Research News, 19 (4/5), 38-40. http://dx.doi.org/10.1108/eb028456

48. Tushman, M. L., \& O'Reilly, C. A. (2002). Winning through Innovation: A Practical Guide to Leading Organizational Change and Renewal. Boston, M. A: Harvard Business School Press.

49. Verbeeten, F. H. M. (2008). Performance Management Practices in Public Sector Organizations: Impact on Performance. Accounting, Auditing and Accountability Journal, 21(3), 427-454. http://dx.doi.org/10.1108/09513570810863996

50. Wilkins, A., \& Ouchi, W. G. (1983). Efficient Cultures: Exploring the Relationship Between Culture and Organizational Performance. Administrative Science Quarterly. 28(3), 468-481. http://dx.doi.org/10.2307/2392253

\section{Contact information}

Omotayo Adewale OSIBANJO (Ph.D)

Business Management Department, School of Business

College of Development Studies, Covenant University

Ota, Ogun State, Nigeria

Email:ade.osibanjo@covenantuniversity.edu.ng

Adenike Anthonia ADENIJI (Ph.D)

Business Management Department, School of Business

College of Development Studies, Covenant University

Ota, Ogun State, Nigeria

Email:Anthonia.adeniji@covenantuniversity.edu.ng 


\section{Appendix}

Instruction: Please tick the appropriate answer in the box provided.

\section{Respondent Demography:}

1. Gender:

2. Age: $18-25 \mathrm{yrs}$

3. Marital Status: Single

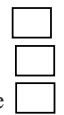

Male<smiles>C1=CCCC1</smiles>

Female

4. Work Experience: $0-5$ years

$26-35$ yrs

Married

$36-45 \mathrm{yrs}$

$\square$ Divorced

46yrs \& Above

Others

\section{$\mathbf{S} / \mathbf{n}$}

Statements

6 - 10 years

11years \& above

\begin{tabular}{|c|c|c|c|c|c|c|}
\hline $\mathbf{S} / \mathbf{n}$ & Statements & $\begin{array}{c}\mathbf{5} \\
\mathrm{SA} \\
\end{array}$ & $\begin{array}{l}4 \\
\mathrm{~A}\end{array}$ & $\begin{array}{l}3 \\
\mathrm{U} \\
\end{array}$ & $\begin{array}{l}2 \\
\mathrm{~A}\end{array}$ & $\begin{array}{c}1 \\
\text { SD } \\
\end{array}$ \\
\hline \multicolumn{7}{|c|}{ Organizational Culture \& Recruitment and Selection } \\
\hline 1 & $\begin{array}{l}\text { Organizational belief positively affects recruitment of highly performing } \\
\text { individuals }\end{array}$ & & & & & \\
\hline 2 & Organizational value positively affects individuals objectives & & & & & \\
\hline 3 & Organizational belief positively affects recruitment process & & & & & \\
\hline 4 & Organizational value positively affects individual values and culture & & & & & \\
\hline \multicolumn{7}{|c|}{ Training \& Development Programmes and Organizational Culture } \\
\hline 5 & Training programmes should be aligned with the organizational value & & & & & \\
\hline 6 & $\begin{array}{l}\text { Organizational belief and social presence positively affect information sharing } \\
\text { process which comes via training and development programmes }\end{array}$ & & & & & \\
\hline 7 & Training and development positively improve the organizational belief & & & & & \\
\hline 8 & $\begin{array}{l}\text { Training and development help create better corporate image which aids } \\
\text { organizational development }\end{array}$ & & & & & \\
\hline \multicolumn{7}{|c|}{ Organizational Culture and Performance Management } \\
\hline 9 & Organizational value positively affects job performance management & & & & & \\
\hline 10 & Organizational belief positively affects performance of employees & & & & & \\
\hline 11 & Employee performance affects organizational growth and development & & & & & \\
\hline \multicolumn{7}{|c|}{ Organizational Culture and Compensation Administration } \\
\hline 12 & Pay structures depends on the kind of value an organization adopts & & & & & \\
\hline 13 & $\begin{array}{l}\begin{array}{l}\text { Compensation administrators always seek to achieve internal equity and } \\
\text { consistency through organizational belief }\end{array} \\
\end{array}$ & & & & & \\
\hline 14 & $\begin{array}{l}\text { The general model of compensation administration focus on the belief of the } \\
\text { organization }\end{array}$ & & & & & \\
\hline 15 & $\begin{array}{l}\text { Achieving external competitiveness in the area of compensation should be in line } \\
\text { with the corporate value }\end{array}$ & & & & & \\
\hline 16 & $\begin{array}{l}\text { An organization' practice of compensation administration involves the weight an } \\
\text { organization chose to place on employee performance }\end{array}$ & & & & & \\
\hline
\end{tabular}

